\title{
Genetic Characterization of Goutanap Virus, a Novel Virus Related to Negeviruses, Cileviruses and Higreviruses
}

\section{René Kallies ${ }^{1, \dagger}$, Anne Kopp ${ }^{1, \dagger}$, Florian Zirkel ${ }^{1}$, Alejandro Estrada ${ }^{2}$, Thomas R. Gillespie ${ }^{3,4}$, Christian Drosten ${ }^{1}$ and Sandra Junglen ${ }^{1, *}$}

1 Institute of Virology, Medical Centre, University of Bonn, Sigmund-Freud-Str. 25, 53127 Bonn, Germany; E-Mails: rene.kallies@ufz.de (R.K.); kopp@virology-bonn.de (A.K.); zirkel@virology-bonn.de (F.Z.); drosten@virology-bonn.de (C.D.)

2 Estación de Biología Tropical Los Tuxtlas, Instituto de Biología, Universidad Nacional Autónoma de México, Apdo 176, San Andres Tuxtla, Veracruz, Mexico; E-Mail: aestrada@primatesmx.com

3 Department of Environmental Sciences and Program in Population Biology, Ecology and Evolution, Emory University, Atlanta, GA 30322, USA; E-Mail: thomas.gillespie@emory.edu

4 Department of Environmental Health, Rollins School of Public Health, Emory University, Atlanta, GA 30322, USA

$\dagger$ These authors contributed equally to this work.

* Present address: Helmholtz Centre for Environmental Research—UFZ, Department of Environmental Microbiology, Permoserstr. 15, 04157 Leipzig, Germany.

* Author to whom correspondence should be addressed; E-Mail: junglen@virology-bonn.de; Tel.: +49-228-287-13064; Fax: +49-228-287-19144.

External Editors: Robert B. Tesh, Bethany Bolling, Scott C. Weaver and Nikolaos Vasilakis Received: 1 August 2014; in revised form: 28 October 2014 / Accepted: 3 November 2014 / Published: 12 November 2014

\footnotetext{
Abstract: Pools of mosquitoes collected in Côte d'Ivoire and Mexico were tested for cytopathic effects on the mosquito cell line C6/36. Seven pools induced strong cytopathic effects after one to five days post infection and were further investigated by deep sequencing. The genomes of six virus isolates from Côte d'Ivoire showed pairwise nucleotide identities of $\sim 99 \%$ among each other and of $56 \%-60 \%$ to Dezidougou virus and Wallerfield virus, two insect-specific viruses belonging to the proposed new taxon Negevirus. The novel virus was tentatively named Goutanap virus. The isolate derived
} 
from the Mexican mosquitoes showed 95\% pairwise identity to Piura virus and was suggested to be a strain of Piura virus, named C6.7-MX-2008. Phylogenetic inferences based on a concatenated alignment of the methyltransferase, helicase, and RNA-dependent RNA polymerase domains showed that the new taxon Negevirus formed two monophyletic clades, named Nelorpivirus and Sandewavirus after the viruses grouping in these clades. Branch lengths separating these clades were equivalent to those of the related genera Cilevirus, Higrevirus and Blunervirus, as well as to those within the family Virgaviridae. Genetic distances and phylogenetic analyses suggest that Nelorpivirus and Sandewavirus might form taxonomic groups on genus level that may define alone or together with Cilevirus, Higrevirus and Blunervirus a viral family.

Keywords: negevirus; insect-specific viruses; mosquito; next generation sequencing; virus taxonomy

\section{Introduction}

Mosquitoes transmit a great diversity of viruses that can cause severe disease in humans, e.g., Yellow fever virus, Dengue virus, and Chikungunya virus [1-3]. Pathogens that can replicate in mosquitoes and vertebrates, so called arboviruses, are members of six virus families, Bunyaviridae, Flaviviridae, Togaviridae, Reoviridae, Rhabdoviridae and Asfarviridae. Within recent years, novel viruses that seem to infect insects only and not to be able to replicate in vertebrates have been discovered in mosquitoes. These insect-specific or insect-restricted viruses belong not only to viral families that contain arboviruses [4-12] but also to clades in large phylogenetic distance to established families [13-15] suggesting that an even larger genetic diversity of insect-specific viruses exists in mosquitoes. Understanding the ecology and evolution of these viruses will also help to shed light on the evolution of arboviruses. Moreover, studies are needed that investigate the influence of insect-specific viruses on the replication and transmission of arboviruses.

One of these new taxa of insect-specific viruses is the recently proposed new taxon Negevirus [15]. Negeviruses were isolated from mosquitoes and phlebotomine sand flies collected in North and South America, Africa and Asia [15-17]. Viral particles are spherical with a size of 45 to $55 \mathrm{~nm}$ in diameter [15]. The single-stranded positive sense RNA genome is approximately 9 to $10 \mathrm{~kb}$ in length and comprises three open reading frames (ORF) that are flanked by untranslated regions and are separated by intergenic regions. The large ORF1 is predicted to represent the replicase gene. The encoded protein contains methyltransferase, ribosomal RNA methyltransferase, helicase and RNA-dependent RNA polymerase (RdRp) domains. ORF2 encodes a protein with membrane-spanning domains that may function as a structural protein. The role of the putative protein encoded by ORF3 is unknown. Phylogenetic analyses identified the plant-infecting Citrus leprosis $\mathrm{C}$ virus (CiLV-C) as closest relative. CiLV-C is transmitted by mites and is the only member of the genus Cilevirus (unassigned family) [18]. Other related plant infecting viruses are Hibiscus green spot virus (HGSV), the type species of the genus Higrevirus (unassigned family), and Blueberry necrotic ring blotch virus (BNRBV), proposed to be the type species of the genus Blunervirus (unassigned family) [19]. 
Phylogenetic analyses of the RdRp indicated similarities of CiLV-C, HGSV and BNRBV to the plant-infecting family Virgaviridae [19-23].

Here, we report the detection of a novel virus, named Goutanap virus (GANV), after the village Gouléako and Taï National Park in Côte d'Ivoire from which the mosquitoes originated, as well as of 33 strains of Piura virus (PIUV) from mosquitoes collected in Mexico.

\section{Materials and Methods}

\subsection{Mosquito Collection and Virus Isolation}

Mosquitoes were collected in the area of the Taï National Park in Côte d'Ivoire [24] and of the Palenque National Park in Mexico [25] and used for virus isolation as described [26]. Mosquitoes were identified using the identification keys of Darsie (2005) [27], Carpenter (1955) [28], and Clark-Gil (1983) [29] for the Mexican mosquitoes and the identification keys of Jupp (1996) [30], Edwards (1941) [31], Gillies de Meillon (1968) [32] and Gillies and Coetzee (1987) [33] for the African mosquitoes, respectively. In total, 371 pools consisting of 3491 mosquitoes collected in Mexico and 432 pools containing 4839 mosquitoes collected in Côte d'Ivoire were analysed. Several other viruses have been identified in the same material [7-9,11,24-26,34,35]. Briefly, mosquitoes were pooled according to species or genus [25,26] and homogenized. Aedes albopictus (C6/36) and African green monkey (Vero E6/7) cells were infected with mosquito homogenates and observed for cytopathic effects (CPE). CPE positive cultures were used to infect confluent C6/36 cells in $175 \mathrm{~cm}^{2}$ cell culture flasks. Virus particles were pelleted by ultracentrifugation through a $36 \%$ sucrose cushion, re-suspended in $200 \mu \mathrm{L}$ PBS and stored at $-80^{\circ} \mathrm{C}$ until further analysis.

\subsection{Nucleic Acid Extraction and Next Generation Sequencing}

Viral nucleic acids from Ivorian samples were extracted using TRIzol (Life Technologies, Darmstadt, Germany) and double-strand cDNA was synthesized using the cDNA Synthesis System Kit (Roche, Mannheim, Germany) following the manufacturer's instructions. One hundred nanograms (ng) of cDNA per sample were fragmented as described in the Ion Xpress Plus gDNA Fragment Library Preparation Manual (Life Technologies). Fragment ends were repaired, barcode containing adapter oligonucleotides were ligated and emulsion PCR (emPCR) was performed according to the Ion Torrent protocol (Life Technologies). Next Generation Sequencing (NGS) was performed on a 316 chip using the Ion Torrent platform (Life Technologies). Viral nucleic acids from Mexican samples were extracted using the RNeasy Mini Kit (Qiagen, Hilden, Germany) and cDNA synthesis was performed with the Superscript OneCycle cDNA Kit (Life Technologies) according to the manufacturer's instructions. Fragmentation of $100 \mathrm{ng}$ cDNA per sample was done by nebulization and a library was constructed according to the GS Junior Titanium Series Rapid Library Preparation Method Manual (Roche). Fragment end repair, adaptor ligation and emPCR (Kit Lib-L) were done following the standard Roche protocols. NGS was performed on a Roche 454 GS Junior system. 


\subsection{Analysis of NGS Reads and Phylogenetic Analyses}

NGS reads were assembled in Geneious v6 and contigs were aligned against the GenBank virus database using the blastn and blastx algorithms [36]. Conserved protein domains were identified using the Conserved Domain Database webserver [37]. For calculation of nucleotide (nt) identity matrices nucleotide sequences were aligned using ClustalW [38]. For phylogenetic analyses concatenated amino acid (aa) alignments of the methyltransferase, the helicase and the RdRp conserved protein domains of all available negeviruses, CiLV-C, HGSV, BNRBV and of representative members from all genera of the family Virgaviridae (Table S1) were aligned using MAFFT v7 [39]. Phylogenetic trees were inferred in PhyML on a gap-free alignment with the Blosum62 and Dayhoff substitution matrix and 1000 bootstrap replications [40].

\subsection{PCR Screening}

RNA was extracted from cytopathic cell culture supernatants that were inoculated with homogenates of the Mexican mosquitoes using the Nucleo spin RNA virus Kit (Machery and Nagel, Düren, Germany). cDNA was synthesized using random hexamer primers and Superscript III Reverse transcriptase (Life Technologies). PCR was performed using Platinum Taq polymerase (Life Technologies, Darmstadt, Germany), the primers MX_C6.7_F1 (5'-CTTGAGATTAAGTTCTTCGAGTTTGAGC) and MX_C6.7_R1 (5'-AAAGGCGGTGTGATCGGTG) and $1 \mu \mathrm{L}$ template cDNA. PCR products were visualized by agarose gel electrophoresis and Sanger sequenced (SeqLab, Göttingen, Germany).

\subsection{Nucleotice Sequence Accession Numbers}

The genome sequences of Goutanap virus were assigned to GenBank accession numbers KM249339 and KF588035 to KF588039. The genome sequence of Piura virus C6.7-MX-2008 was assigned to GenBank accession number KM249340. Sequence fragments of the RdRp domain of other Piura virus isolates were assigned to GenBank accession numbers KM258581 to KM258599 and KM924386 to KM924398.

\section{Results and Discussion}

Seven mosquito pools induced strong CPE one to five days post infection in C6/36 cells and were further investigated by NGS (Table 1). Genomes were assembled and compared to viral sequences in the NCBI database revealing that seven negevirus-like viruses were identified. Maximum pairwise nucleotide identities between $56 \%$ to $60 \%$ of the six isolates originating from Côte d'Ivoire were found to Wallerfield virus (WALV) and to Dezidougou virus (DEZV). Pairwise identities among the six novel genomes were $99.3 \%$ to $100 \%$ on nt level and $99.6 \%$ to $100 \%$ on aa level suggesting the detection of six isolates of one novel virus species. We designated this virus GANV. Genome organization of GANV was similar to WALV and DEZV and other negevirus-like viruses [15-17]. GANV genomes ranged between 9141 and $9170 \mathrm{nt}$ in length and comprised three ORFs that were separated by intergenic regions and flanked by UTRs (Table 2). A poly-A tail at the 3'-end of the genomes was detected indicating a positive sense RNA genome. ORFs were further analyzed for conserved protein domains. Five domains were predicted for ORF1: a methyltransferase domain 
(nt 298 to 1377), a ribosomal RNA methyltransferase domain (nt 2392 to 2949), a helicase domain (nt 3985 to 4797), and a RdRp domain (nt 5431 to 6738) (nt positions refer to GANV F33-CI-2004). Similar to other negevirus-like sequences, no conserved domains were identified for ORF2 and ORF3.

Table 1. GANV and PIUV positive mosquito pools. Mosquitoes have been collected in Côte d'Ivoire (CI) in 2004 and in Mexico (MX) in 2008.

\begin{tabular}{|c|c|c|c|c|}
\hline Virus & Isolate & Host Taxon & $\begin{array}{c}\text { No. of } \\
\text { Individuals }\end{array}$ & $\begin{array}{l}\text { Trapping } \\
\text { Locality } \\
\end{array}$ \\
\hline GANV & C68-CI-2004 & Culicidae spp. & 10 & $\begin{array}{c}\text { Secondary } \\
\text { rainforest, } \mathrm{CI}\end{array}$ \\
\hline GANV & F33-CI-2004 & Culex nebulosus & 12 & Gouléako, CI \\
\hline GANV & F35-CI-2004 & Culex nebulosus & 16 & Gouléako, CI \\
\hline GANV & F47-CI-2004 & Culicinae spp. & 10 & Taï, CI \\
\hline GANV & F54-CI-2004 & Culex antenatus & 20 & Taï, CI \\
\hline GANV & F55-CI-2004 & Culex antenatus & 9 & Taï, CI \\
\hline PIUV & C6.7-MX-2008 & Mansonia spp., Wyeomyia spp. & 10 & Palenque, MX \\
\hline PIUV & A2.1-MX-2008 & Trichoprosopon spp., Coquillettidia spp. & 10 & Palenque, MX \\
\hline PIUV & A8.5-MX-2008 & Culex spp. & 10 & Palenque, MX \\
\hline PIUV & A11.18-MX-2008 & Culex spp. & 10 & Palenque, MX \\
\hline PIUV & A11.22-MX-2008 & Culex spp. & 10 & Palenque, $\mathrm{MX}$ \\
\hline PIUV & B1.2-MX-2008 & Psorophora spp. & 10 & Palenque, $\mathrm{MX}$ \\
\hline PIUV & B1.3-MX-2008 & Culex spp. & 10 & Palenque, MX \\
\hline PIUV & B1.4-MX-2008 & Culex spp., Trichoprosopon spp. & 10 & Palenque, $\mathrm{MX}$ \\
\hline PIUV & B1.5-MX-2008 & Culex spp., Trichoprosopon spp. & 10 & Palenque, $\mathrm{MX}$ \\
\hline PIUV & B1.6-MX-2008 & Culex spp., Wyeomyia spp. & 10 & Palenque, $\mathrm{MX}$ \\
\hline PIUV & B2.3-MX-2008 & Culex spp., Wyeomyia spp., Psorophora spp. & 10 & Palenque, $\mathrm{MX}$ \\
\hline PIUV & B5.21-MX-2008 & Wyeomyia spp., Trichoprosopon spp. & 10 & Palenque, MX \\
\hline PIUV & B8.9-MX-2008 & Culex spp. & 10 & Palenque, $\mathrm{MX}$ \\
\hline PIUV & B8.10-MX-2008 & Culex spp. & 10 & Palenque, MX \\
\hline PIUV & B8.11-MX-2008 & Culex spp. & 10 & Palenque, $\mathrm{MX}$ \\
\hline PIUV & B8.12-MX-2008 & Culex spp. & 10 & Palenque, $\mathrm{MX}$ \\
\hline PIUV & B8.13-MX-2008 & Culex spp. & 10 & Palenque, MX \\
\hline PIUV & B8.14-MX-2008 & Culex spp. & 10 & Palenque, $\mathrm{MX}$ \\
\hline PIUV & B10.1-MX-2008 & $\begin{array}{c}\text { Culex spp., Psorophora spp., Mansonia spp., } \\
\text { Toxorhynchites spp. }\end{array}$ & 9 & Palenque, MX \\
\hline PIUV & B10.2-MX-2008 & Culex spp. & 10 & Palenque, MX \\
\hline PIUV & B10.3-MX-2008 & Culex spp. & 10 & Palenque, $\mathrm{MX}$ \\
\hline PIUV & C1.20-MX-2008 & Culex spp. & 10 & Palenque, MX \\
\hline PIUV & C1.22-MX-2008 & Culex spp. & 10 & Palenque, MX \\
\hline PIUV & C1.24-MX-2008 & Culex spp. & 10 & Palenque, $\mathrm{MX}$ \\
\hline PIUV & C1.25-MX-2008 & Culex spp. & 2 & Palenque, $\mathrm{MX}$ \\
\hline PIUV & C5.2-MX-2008 & Mansonia spp., Wyeomyia spp. & 10 & Palenque, $\mathrm{MX}$ \\
\hline PIUV & C6.6-MX-2008 & Culex spp. & 9 & Palenque, MX \\
\hline PIUV & C6.9-MX-2008 & Mansonia spp. & 10 & Palenque, $\mathrm{MX}$ \\
\hline PIUV & C7.1-MX-2008 & Culex spp., Aedes spp. *, Toxorhynchites spp. & 10 & Palenque, MX \\
\hline PIUV & C7.2-MX-2008 & Culex spp., Mansonia spp., Wyeomyia spp. & 10 & Palenque, MX \\
\hline PIUV & D2.1-MX-2008 & Culex spp. & 10 & Palenque, $\mathrm{MX}$ \\
\hline PIUV & D2.2-MX-2008 & Culex spp. & 10 & Palenque, MX \\
\hline PIUV & D2.3-MX-2008 & Culex spp. & 8 & Palenque, $\mathrm{MX}$ \\
\hline
\end{tabular}

* Based on the old classification system. 
Isolate C6.7-MX-2008 originating from Palenque, Mexico showed 94.8\% nt identity and 98.4\% aa identity to PIUV P60 from Peru [15] and was thus suggested to be a novel strain of PIUV, named PIUV Palenque C6.7-MX-2008. Genome organization of PIUV Palenque C6.7-MX-2008 is shown in Table 2. RT-PCR screening of additional cytopathic cell cultures inoculated with Mexican mosquitoes yielded 32 cultures also infected with PIUV (Table 1). Sequence fragments showed $95.3 \%$ to $100 \% \mathrm{nt}$ identity and $97.2 \%$ to $100 \%$ aa identity among each other indicating that all isolates were strains of PIUV. Infected mosquito pools mainly contained Culex mosquitoes but also species of the genera Aedes, Mansonia, Psorophora, and Wyeomyia showing that PIUV infects a large diversity of mosquito species (Table 1). Thus far, negevirus-like viruses were only identified in mosquitoes of the genera Anopheles, Culex, and Armigeres [15-17]. The infection rate was with 32\% (33/102 pools) extremely high. No other studies investigating the negevirus infection rate in mosquitoes have been reported so far. However, the detection of these viruses in several countries on different continents suggests a wide distribution and a high prevalence in mosquito populations. It has recently been shown that the co-infection of mosquitoes with an insect-specific flavivirus may enhance or suppress the transmission of a mosquito-borne flavivirus [41-43]. Thus, it will be of great interest to study if these viruses may influence infection, replication and transmission of arboviruses by mosquitoes.

Table 2. Genome organization of GANV and PIUV C6.7-Mx-2008.

\begin{tabular}{lccccccccc}
\hline Virus & Strain & Genome & $\mathbf{5}^{\prime}$ UTR * & ORF1 & $\begin{array}{c}\text { Intergenic } \\
\text { Region }\end{array}$ & ORF2 & $\begin{array}{c}\text { Intergenic } \\
\text { Region }\end{array}$ & ORF3 & 3'UTR * \\
\hline GANV & C68-CI-2004 & 9151 & 63 & 6732 & 31 & 1233 & 98 & 660 & 334 \\
GANV & F33-CI-2004 & 9165 & 66 & 6732 & 31 & 1233 & 98 & 660 & 335 \\
GANV & F35-CI-2004 & 9170 & 66 & 6732 & 31 & 1233 & 98 & 660 & 341 \\
GANV & F47-CI-2004 & 9141 & 41 & 6732 & 31 & 1233 & 98 & 660 & 337 \\
GANV & F54-CI-2004 & 9164 & 65 & 6732 & 31 & 1233 & 98 & 660 & 336 \\
GANV & F55-CI-2004 & 9168 & 67 & 6732 & 31 & 1233 & 98 & 660 & 336 \\
PIUV & C6.7-MX-2008 & 10018 & 716 & 7011 & 42 & 1203 & 140 & 618 & 288 \\
\hline
\end{tabular}

* incomplete.

Phylogenetic analyses based on conserved RdRp domains grouped GANV in a basal phylogenetic position to the two sister species WALV and DEZV (Figure 1A). The three viruses formed a monophyletic clade with Santana virus (SANV) and Tanay virus (TANAV), tentatively designated Sandewavirus after the first viruses that were described in this clade (from $\underline{\text { Santana, Dezidougou and }}$ Wallerfield). PIUV Palenque C6.7-MX-2008 clustered together with PIUV P60, Negev virus (NEGV), Ngewotan virus (NWTV), and Loreto virus (LORV) (Figure 1A). This clade was tentatively named Nelorpivirus after Negevirus, Loreto and Piura. Plant infecting viruses of the genera Cilevirus, Higrevirus and Blunervirus paired in sister relationship to all members of the taxon Negevirus with Blunervirus branching close to the tree root on a solitary branch. This topology was not contradicting the topologies presented by Auguste et al. (2014) [16], Nabeshima et al. (2014) [17] and Vasilakis et al. (2013) [15]. Intra- and intergenetic distances for the clades are shown in Table 3.

In an attempt to root the phylogeny we repeated the phylogenetic analysis based on concatenated protein sequences of the methyltransferase, helicase and $\mathrm{RdRp}$ domains including representative members of each genus of the Virgaviridae, a closely related family (Figure 1B). In this phylogeny 
using virgaviruses as an outgroup, the ingroup root was placed at a different location separating Sandewavirus from other negeviruses, as well as the genera Cilevirus, Higrevirus and Blunervirus.

Table 3. Intra- and interclade amino acid pairwise identity values of Nelorpivirus, Sandewavirus, Cilevirus, Higrevirus and Blunervirus. Classification into five clades was based on ML analyses as shown in Figure 1.

\begin{tabular}{cccccc}
\hline Clade & Nelorpivirus & Sandewavirus & Cilevirus & Higrevirus & Blunervirus \\
\hline Nelorpivirus & $54.1-72.1$ & & & & \\
Sandewavirus & $30.1-33.4$ & $58.0-70.8$ & & & \\
Cilevirus & $32.2-32.7$ & $25.5-26.9$ & $/$ & & \\
Higrevirus & $31.0-31.8$ & $25.3-27.3$ & 41.7 & $/$ & \\
Blunervirus & $28.4-29.5$ & $23.7-25.8$ & 25.4 & 25.6 & $/$ \\
\hline
\end{tabular}

However, based on genome organization and host association, the topology in Figure 1A seems more likely than the topology in Figure 1B, as viruses with similar genome organizations and hosts cluster with each other in Figure 1A. The insect-infecting viruses have a genome consisting of one segment of positive-sense RNA while the genomes of plant-infecting cile-, higre-, and blunerviruses are two-, three-, and four-segmented, respectively (and double-stranded in case of Blunervirus). However, the clustering of Blunervirus with other plant-infecting viruses might as well result from a long-branch attraction effect that could resolve upon inclusion of further (as yet unknown) taxa on this solitary branch.

According to phylogenetic distances separating established genera within the family Virgaviridae the tree topology suggests that Nelorpivirus and Sandewavirus might form taxonomic groups on genus level. Differences in genome architecture may not suffice to define whether Nelorpivirus and Sandewavirus alone or in combination with Cilevirus, Higrevirus and Blunervirus define a viral family, as differences in the number of genomic RNAs of different genera are known in other viral families, e.g., Viragviridae [21,23] and Reoviridae [44].

In summary, phylogenetic analyses suggest that the taxon Negevirus as presented in Vasilakis et al. (2013) [15] is a monophyletic taxon in which several distinct genera and potentially higher taxonomic units exist. Our finding of GANV corroborates the existence of clearly separated subgroups within two major Negevirus clades (Nelorpivirus and Sandewavirus). All negeviruses share one type of genome organization (non-segmented, positive-sense ssRNA) as opposed to outgroup taxa, which in turn have heterogeneous genome organizations, predicting the taxon Negevirus to constitute a candidate virus family or subfamily. The high infection rate of Nelorpivirus and Sandewavirus in mosquito populations and their wide geographic distribution invites further studies on the influence of negeviruses on mosquito populations as well as the transmission of mosquito-borne disease. 

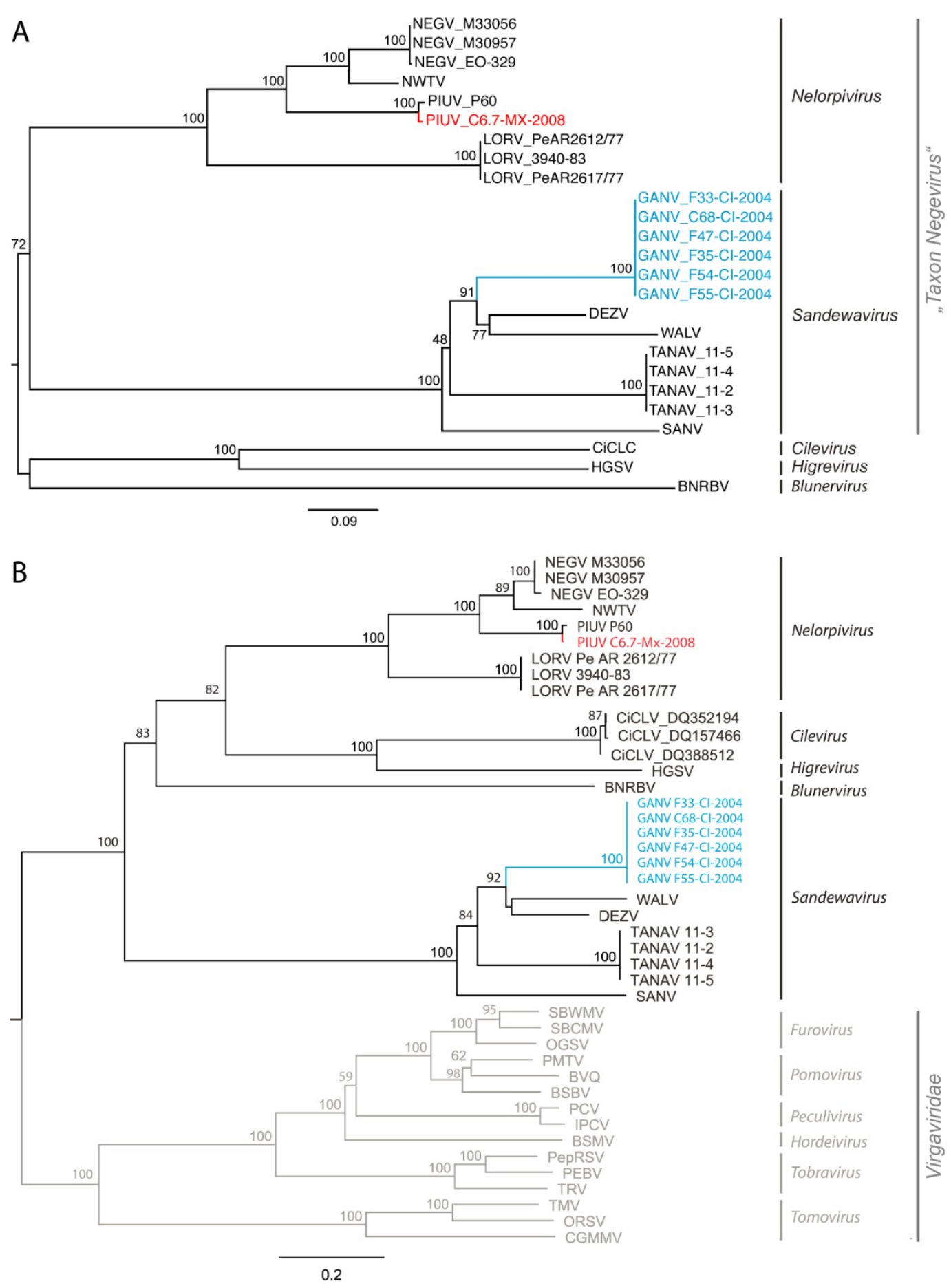

Nelorpivirus

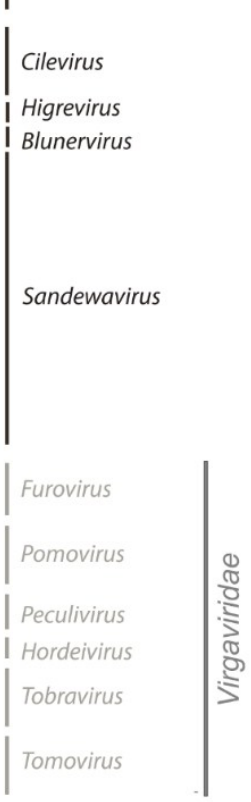

Figure 1. Phylogenetic relationship of Goutanap virus and Piura virus C6.7-MX-2008. (A) Analysis of the conserved domains of the RNA-dependent RNA polymerase proteins of negeviruses, cileviruses, higreviruses and blunerviruses; (B) Analysis of a gap-free concatenated alignment of fused methyltransferase, helicase and RNA-dependent RNA polymerase domains of members of negeviruses, cileviruses, higreviruses and blunerviruses, as well as representative members of each genus of the Virgaviridae family. ML analyses were based on an 805 amino acid alignment (A) and a 445 amino acid alignment (B) guided by the Blosum62 (A) and Dayhoff (B) substitution matrix using PHYML as implemented in Geneious. Confidence testing was performed with 1000 bootstrap replicates. Virus names and GenBank accession numbers are provided in Table S1. 


\section{Acknowledgments}

We thank the Ivorian Ministry of Environment and Forest and the Ministry of Research, as well as the directorship of the Taï National Park for permission to conduct this research. We also thank the Ministry of Natural Protected Areas of Mexico (CONANP) for permission to work in Palenque National Park. We are grateful to Fabian Leendertz for assistance with fieldwork research design and logistic support. We are grateful to Daniel Hobelsberger for helping with mosquito sampling in Mexico. We are grateful to Annika Branting and Priyal de Zoysa for support with Ion Torrent Sequencing.

This work was financially supported by the Deutsche Forschungsgemeinschaft (grant agreement number JU 2857/3-1 to Sandra Junglen).

\section{Author Contributions}

S.J. did field work. A.E. and T.R.G. organised field work in Mexico. S.J. and A.K. performed virus isolation experiments. R.K. and F.Z. performed Next Generation sequencing and bioinformatic analysis. R.K. and S.J. did phylogenetic analyses. C.D. and S.J. designed the study. R.K., S.J. and C.D. wrote the paper that was finally approved by all authors.

\section{Conflicts of Interest}

The authors declare no conflict of interest.

\section{References and Notes}

1. Monath, T.P. Yellow fever: An update. Lancet Infect. Dis. 2001, 1, 11-20.

2. Guzman, M.G.; Halstead, S.B.; Artsob, H.; Buchy, P.; Farrar, J.; Gubler, D.J.; Hunsperger, E.; Kroeger, A.; Margolis, H.S.; Martínez, E.; et al. Dengue: A continuing global threat. Nat. Rev. Microbiol. 2010, 8, S7-S16.

3. Burt, F.J.; Rolph, M.S.; Rulli, N.E.; Mahalingam, S.; Heise, M.T. Chikungunya: A re-emerging virus. Lancet 2012, 379, 662-671.

4. Cook, S.; Bennett, S.N.; Holmes, E.C.; de Chesse, R.; Moureau, G.; de Lamballerie, X. Isolation of a new strain of the flavivirus cell fusing agent virus in a natural mosquito population from Puerto Rico. J. Gen. Virol. 2006, 87, 735-748.

5. Calzolari, M.; Zé-Zé, L.; Růžek, D.; Vázquez, A.; Jeffries, C.; Defilippo, F.; Osório, H.C.; Kilian, P.; Ruíz, S.; Fooks, A.R.; et al. Detection of mosquito-only flaviviruses in Europe. J. Gen. Virol. 2012, 93, 1215-1225.

6. Ma, H.; Galvin, T.A.; Glasner, D.R.; Shaheduzzaman, S.; Khan, A.S. Identification of a Novel Rhabdovirus in Spodoptera frugiperda Cell Lines. J. Virol. 2014, 88, 6576-6585.

7. Quan, P.L.; Junglen, S.; Tashmukhamedova, A.; Conlan, S.; Hutchison, S.K.; Kurth, A.; Ellerbrok, H.; Egholm, M.; Briese, T.; Leendertz, F.H.; et al. Moussa virus: A new member of the Rhabdoviridae family isolated from Culex decens mosquitoes in Côte d'Ivoire. Virus Res. 2010, $147,17-24$. 
8. Marklewitz, M.; Gloza-Rausch, F.; Kurth, A.; Kümmerer, B.M.; Drosten, C.; Junglen, S. Gouleako virus isolated from West African mosquitoes constitutes a proposed novel genus in the family Bunyaviridae. J. Virol. 2011, 85, 9227-9234.

9. Marklewitz, M.; Zirkel, F.; Rwego, I.B.; Heidemann, H.; Trippner, P.; Kurth, A.; Kallies, R.; Briese, T.; Lipkin, W.I.; Drosten, C.; et al. Discovery of a unique novel clade of mosquito-associated bunyaviruses. J. Virol. 2013, 87, 12850-12865.

10. Spear, A.; Sisterson, M.S.; Stenger, D.C. Reovirus genomes from plant-feeding insects represent a newly discovered lineage within the family Reoviridae. Virus Res. 2012, 163, 503-511.

11. Hermanns, K.; Zirkel, F.; Kurth, A.; Drosten, C.; Junglen, S. Cimodo virus belongs to a novel lineage of reoviruses isolated from African mosquitoes. J. Gen. Virol. 2014, 95, 905-909.

12. Nasar, F.; Palacios, G.; Gorchakov, R.V.; Guzman, H.; da Rosa, A.P.; Savji, N.; Popov, V.L.; Sherman, M.B.; Lipkin, W.I.; Tesh, R.B.; et al. Eilat virus, a unique alphavirus with host range restricted to insects by RNA replication. Proc. Natl. Acad. Sci. USA 2012, 109, 14622-14627.

13. Zirkel, F.; Kurth, A.; Quan, P.L.; Briese, T.; Ellerbrok, H.; Pauli, G.; Leendertz, F.H.; Lipkin, W.I.; Ziebuhr, J.; Drosten, C.; et al. An insect nidovirus emerging from a primary tropical rainforest. MBio 2011, 2, e00077-11.

14. Nga, P.T.; Parquet Mdel, C.; Lauber, C.; Parida, M.; Nabeshima, T.; Yu, F.; Thuy, N.T.; Inoue, S.; Ito, T.; Okamoto, K.; et al. Discovery of the first insect nidovirus, a missing evolutionary link in the emergence of the largest RNA virus genomes. PLoS Pathog. 2011, 7, e1002215.

15. Vasilakis, N.; Forrester, N.L.; Palacios, G.; Nasar, F.; Savji, N.; Rossi, S.L.; Guzman, H.; Wood, T.G.; Popov, V.; Gorchakov, R.; et al. Negevirus: A proposed new taxon of insect-specific viruses with wide geographic distribution. J. Virol. 2013, 87, 2475-2488.

16. Auguste, A.J.; Carrington, C.V.; Forrester, N.L.; Popov, V.L.; Guzman, H.; Widen, S.G.; Wood, T.G.; Weaver, S.C.; Tesh, RB. Characterization of a novel Negevirus and a novel Bunyavirus isolated from Culex (Culex) declarator mosquitoes in Trinidad. J. Gen. Virol. 2014, 95, 481-485.

17. Nabeshima, T.; Inoue, S.; Okamoto, K.; Posadas-Herrera, G.; Yu, F.; Uchida, L.; Ichinose, A.; Sakaguchi, M.; Sunahara, T.; Buerano, C.C.; et al. Tanay virus, a new species of virus isolated from mosquitoes in the Philippines. J. Gen. Virol. 2014, 95, 1390-1395.

18. Locali-Fabris, E.C.; Freitas-Astúa, J.; Souza, A.A.; Takita, M.A.; Astúa-Monge, G.; Antonioli-Luizon, R.; Rodrigues, V.; Targon, M.L.; Machado, M.A. Complete nucleotide sequence, genomic organization and phylogenetic analysis of Citrus leprosis virus cytoplasmic type. J. Gen. Virol. 2006, 87, 2721-2729.

19. Quito-Avila, D.F.; Brannen, P.M.; Cline, W.O.; Harmon, P.F.; Martin, R.R. Genetic characterization of Blueberry necrotic ring blotch virus, a novel RNA virus with unique genetic features. J. Gen. Virol. 2013, 94, 1426-1434.

20. Melzer, M.J.; Sether, D.M.; Borth, W.B.; Hu, J.S. Characterization of a virus infecting Citrus volkameriana with Citrus Leprosis-like symptoms. Phytopathology 2012, 102, 122-127.

21. Adams, M.J.; Heinze, C.; Jackson, A.O.; Macfarlange, S.A.; Torrance, L. Family Virgaviridae. In Virus Taxonomy: Ninth Report of the International Committee on Taxonomy of Viruses; King, A.M.Q., Adams, M.J., Carstens, E.B., Lefkowitz, E.J., Eds.; Elsevier Academic Press: San Diego, CA, USA, 2012; pp. 1139-1162. 
22. Locali-Fabris, E.C.; Freitas-Asutua, J.; Machado, M.A. Genus Cilevirus. In Virus taxonomy: Ninth Report of the International Committee on Taxonomy of Viruses; King, A.M.Q., Adams, M.J., Carstens, E.B., Lefkowitz, E.J., Eds.; Elsevier Academic Press: San Diego, CA, USA, 2012; pp. 1169-1172.

23. Adams, M.J.; Antoniw, J.F.; Kreuze, J. Virgaviridae: A new family of rod-shaped plant viruses. Arch. Virol. 2009, 154, 1967-1972.

24. Junglen, S.; Kurth, A.; Kuehl, H.; Quan, P.L.; Ellerbrok, H.; Pauli, G.; Nitsche, A.; Nunn, C.; Rich, S.M.; Lipkin, W.I.; et al. Examining landscape factors influencing relative distribution of mosquito genera and frequency of virus infection. Ecohealth 2009, 6, 239-249.

25. Kopp, A.; Gillespie, T.R.; Hobelsberger, D.; Estrada, A.; Harper, J.M.; Miller, R.A.; Eckerle, I.; Müller, M.A.; Podsiadlowski, L.; Leendertz, F.H.; et al. Provenance and geographic spread of St. Louis encephalitis virus. MBio 2013, 4, e00322-13.

26. Junglen, S.; Kopp, A.; Kurth, A.; Pauli, G.; Ellerbrok, H.; Leendertz, F.H. A new flavivirus and a new vector: Characterization of a novel flavivirus isolated from uranotaenia mosquitoes from a tropical rain forest. J. Virol. 2009, 83, 4462-4468.

27. Darsie, R.F.; Ward, R.A. Identification and Geographical Distribution of the Mosquitoes of North America, North of Mexico; University of Florida Press: Gainesville, FL, USA, 2005.

28. Carpenter, S.J.; Lacasse, W.J. Mosquitoes of North America, North of Mexico; University of California Press: Berkeley, CA, USA, 1955.

29. Clark-Gil, S.Y.; Darsie, R.F. The mosquitoes of guatemala, their identification, distribution and bionomics, with keys to adults females and larvae. Mosq. Syst. 1983, 15, 151-284.

30. Jupp, P. Mosquitoes of Southern Africa; Ekoglide Publishers: Hartebeespoort, South Africa, 1996.

31. Edwards, F.W. Mosquitoes of the Ethiopian Region: III Culicine Adults and Pupae; British Museum (Natural History): London, UK, 1941.

32. Gillies, M.T.; de Meillon, B. The Anophelinae of Africa South of the Sahara (Afrotropical Region); The South African Institute for Medical Research: Johannesburg, South Africa, 1968.

33. Gillies, M.T.; Coetzee, M. A supplement to the Anophelinae of Africa South of the Sahara (Afrotropical Region); The South African Institute for Medical Research: Johannesburg, South Africa, 1987.

34. Schuster, S.; Zirkel, F.; Kurth, A.; van Cleef, K.W.R.; Drosten, C.; van Rij, R.P.; Junglen, S. A unique Nodavirus with novel features: Mosinovirus expresses two subgenomic RNAs, a capsid gene of unknown origin, and a suppressor of the antiviral RNAi pathway. J. Virol. 2014, $88,13447-13459$.

35. Zirkel, F.; Roth, H.; Kurth, A.; Drosten, C.; Ziebuhr, J.; Junglen, S. Identification and Characterizaiton of Genetically Divergent Members of the Newly Established Family Mesoniviridae. J. Virol. 2013, 87, 6346-6358.

36. Altschul, S.F.; Gish, W.; Miller, W.; Myers, E.W.; Lipman, D.J. Basic local alignment search tool. J. Mol. Biol. 1990 215, 403-410.

37. Marchler-Bauer, A.; Lu, S.; Anderson, J.B.; Chitsaz, F.; Derbyshire, M.K.; deWeese-Scott, C.; Fong, J.H.; Geer, L.Y.; Geer, R.C.; Gonzales, N.R.; et al. CDD: A Conserved Domain Database for the functional annotation of proteins. Nucleic Acids Res. 2011, 39, 225-229. 
38. Larkin, M.A.; Blackshields, G.; Brown, N.P.; Chenna, R.; McGettigan, P.A.; McWilliam, H.; Valentin, F.; Wallace, I.M.; Wilm, A.; Lopez, R.; et al. Clustal W and Clustal X version 2.0. Bioinformatics 2007, 23, 2947-2948.

39. Katoh, K.; Misawa, K.; Kuma, K.; Miyata, T. MAFFT: A novel method for rapid multiple sequence alignment based on fast Fourier transform. Nucleic Acids Res. 2002, 30, 3059-3066.

40. Guindon, S.; Gascuel, O. A simple, fast, and accurate algorithm to estimate large phylogenies by maximum likelihood. Syst. Biol. 2003, 52, 696-704.

41. Kent, R.J.; Crabtree, M.B.; Miller, B.R. Transmission of West Nile virus by Culex quinquefasciatus say infected with Culex Flavivirus Izabal. PLoS Negl. Trop. Dis. 2010, 4, e671.

42. Bolling, B.G.; Olea-Popelka, F.J.; Eisen, L.; Moore, C.G.; Blair, C.D. Transmission dynamics of an insect-specific flavivirus in a naturally infected Culex pipiens laboratory colony and effects of co-infection on vector competence for West Nile virus. Virology 2012, 427, 90-97.

43. Hobson-Peters, J.; Wei Yee Yam, A.; Wei Fei Lu, J.; Xiang Setoh, Y.; May, F.J.; Kurucz, N.; Walsh, S.; Prow, N.A.; Davis, S.S.; Weir, R.; et al. A New Insect-Specific Flavivirus from Northern Australia Suppresses Replication of West Nile Virus and Murray Valley Encephalitis Virus in Co-infected Mosquito Cells. PLoS One 2013, 8, e56534.

44. Attoui, H.; Mertens, P.P.C.; Becnel, J.; Belaganahalli, S.; Bergoin, M.; Brussaard, C.P.; Chappell, J.D.; Ciarlet, M.; del Vas, M.; Dermody, T.S.; et al. Reoviridae. In Virus Taxonomy: Ninth Report of the International Committee on Taxonomy of Viruses; King, A.M.Q., Adams, M.J., Carstens, E.B., Lefkowitz, E.J., Eds.; Elsevier/Academic Press: Amsterdam, NY, USA, 2012; pp. 541-637.

(C) 2014 by the authors; licensee MDPI, Basel, Switzerland. This article is an open access article distributed under the terms and conditions of the Creative Commons Attribution license (http://creativecommons.org/licenses/by/4.0/). 